\title{
Transepithelial transport of ambroxol hydrochloride across human intestinal Caco-2 cell monolayers
}

\author{
Věra Štětinová, Libuše Smetanová, Dagmar Kholová, Zbyněk Svoboda and Jaroslav Květina \\ Institute of Experimental Biopharmaceutics, Joint Research Centre of the Academy of Sciences of the Czech Republic and \\ PRO.MED.CS Praha a.s., Heyrovského 1207, 50003 Hradec Králové, Czech Republic
}

\begin{abstract}
This study aimed i) to characterize the transepithelial transport of the mucolytic agent ambroxol hydrochloride across the intestinal barrier, ii) to classify the ambroxol according to Biopharmaceutics Classification System (BCS) and iii) to predict ambroxol absorption in humans. Transport of ambroxol $(100,300$ and $1000 \mu \mathrm{mol} / \mathrm{l})$ was studied in a human colon carcinoma cell line Caco-2 in apical to basolateral and basolateral to apical direction, under iso- $\mathrm{pH} 7.4$ and $\mathrm{pH}$-gradient (6 vs. 7.4) conditions. The relative contribution of the paracellular route was estimated using $\mathrm{Ca}^{2+}$-free transport medium. Ambroxol samples from receiver compartments were analysed by HPLC with UV detection ( $242 \mathrm{~nm}$ ).

Results showed that ambroxol transport is linear with time, $\mathrm{pH}$-dependent and direction-independent, displays non-saturable (first-order) kinetics. Thus, the transport seems to be transcellular mediated by passive diffusion. Estimated high solubility and high permeability $\left(\mathrm{P}_{\mathrm{app}}=45 \times 10^{-6}\right.$ $\mathrm{cm} / \mathrm{s}$ ) of ambroxol rank it among well absorbed compounds and class I of BCS. It can be expected that the oral dose fraction of ambroxol absorbed in human intestine is high.
\end{abstract}

Key words: Ambroxol - Caco-2 cells - Transport - Biopharmaceutics Classification System

\section{Introduction}

Ambroxol (2-amino-3,5-dibromo- $N$-[trans-4 hydroxycyclohexyl]benzylamine) is a metabolite of bromhexine used in the treatment of respiratory disorders with productive cough. The major pharmacodynamic actions of ambroxol are surfactant stimulation, mucokinetic and secretagogue activity (Püschmann and Engelhorn 1978; Disse 1987; Malerba and Ragnoli 2008). In addition to the mucolytic activity, ambroxol possesses antioxidant and antiinflammatory properties (Štětinová et al. 2004).

The aim of the present study was to investigate permeability and transepithelial transport mechanisms of the orally administered ambroxol hydrochloride across the human intestinal barrier. Although there are many factors that limit bioavailability of drug, the intestinal epithelium has proved in many cases to be a rate-limiting factor for absorption of orally administered drug molecules (Artursson and Bergström

Correspondence to: Věra Štětinová, Institute of Experimental Biopharmaceutics, Joint Research Centre of the Academy of Sciences of the Czech Republic and PRO.MED.CS Praha a.s., Heyrovského 1207, Hradec Králové 500 03, Czech Republic

E-mail: stetinova@uebf.cas.cz
2004). For this reason, the transepithelial flux of ambroxol was studied using the human colonic carcinoma cell line Caco-2, a standard model of human intestinal absorption as an in vitro tool for prediction of absorption in humans (Artursson et al. 2001). The objectives of this study were: i) to determine whether the ambroxol transport across the Caco-2 monolayer involved an active or a passive mechanism, ii) to evaluate the transcellular and paracellular pathway involves in ambroxol transport, iii) to determine effects of the $\mathrm{pH}$ on ambroxol transport, iv) to classify ambroxol according to Biopharmaceutics Classification System (BCS) (Amidon et al. 1995), and v) to predict ambroxol absorption in humans. BCS was devised to allow prediction of pharmacokinetic performance of drug products based on their permeability and solubility which are the fundamental parameters controlling rate and extent of drug absorption (Wu and Benet 2005).

\section{Materials and Methods}

\section{Materials}

Ambroxol hydrochloride was purchased from Erregierre S.p.A. (Italy). Phenol red, 4-(2-hydroxyethyl)piperazine-1- 
ethanesulfonic acid (HEPES), 2-morpholinoethanesulfonic acid (MES), acetonitrile, methanol, dextromethorphane and scintillation liquid (Universal LSC cocktail) were supplied by Sigma-Aldrich (Praha, Czech Republic). Ammonium acetate and formic acid 98-100\% were from Merck (Říčany, Czech Republic). Dulbecco's modified Eagle's medium (DMEM) with high glucose, Hanks' balanced salt solution (HBSS) with/without $\mathrm{Ca}^{2+}$, Dulbecco's phosphate buffered salt solution (DPBS), trypsin-EDTA (1:250), antibioticantimycotic solution were obtained from PAA Laboratories (BioTech, Praha, Czech Republic). Fetal bovine serum was purchased from Gibco Invitrogen (KRD Molecular Technologies, Praha, Czech Republic) and ${ }^{14} \mathrm{C}$-mannitol (100 $\mu \mathrm{Ci} / \mathrm{ml}$ ) from Moravek Biochemicals and Radiochemicals (M.G.P. Zlín, Czech Republic).

\section{Cell culture}

The Caco-2 cell line was purchased from the European collection of cell culture, Sigma-Aldrich (Praha, Czech Republic) and was used between passages 67 and 77 . The cells were routinely grown (Bourdet and Thakker 2006) in plastic tissue culture flasks ( $75 \mathrm{~cm}^{2}$ growth area, TPP AG, Switzerland) in DMEM containing $25 \mathrm{mmol} / \mathrm{l}$ glucose and supplemented with $4 \mathrm{mmol} / \mathrm{l} \mathrm{L}$-glutamine, 10\% fetal bovine serum, 1\% nonessential amino acids, $100 \mathrm{U} / \mathrm{ml}$ penicillin, $100 \mu \mathrm{g} / \mathrm{ml}$ streptomycin, and $0.25 \mu \mathrm{g}$ amphotericin. Cell line was cultured at $37^{\circ} \mathrm{C}$ in an atmosphere of $5 \% \mathrm{CO}_{2}$ and $90 \%$ relative humidity, and passaged at about $90 \%$ confluence, using $0.05 \%$ trypsin $(1: 250)-0.02 \%$ EDTA in calcium-free and magnesium-free DPBS. The medium was changed three times a week.

\section{Incubation of Caco-2 cells in polycarbonate well inserts}

For ambroxol transport experiments, the cells were seeded onto polycarbonate filter cell culture chamber inserts (dimensions $13 \times 11 \mathrm{~mm}$, area available for growth $0.5 \mathrm{~cm}^{2}$, pore diameter $0.4 \mu \mathrm{m}$ ) of tissue culture plates containing 24 wells (TPP AG, Switzerland) at the density of $2.5 \times 10^{5}$ cells $/ \mathrm{cm}^{2}$. Medium was changed three times a week for 21-25 days, and daily during the last 3-5 days ( $500 \mu$ to the insert compartment - the apical side, and $650 \mu \mathrm{l}$ to the well compartment - the basolateral side). Caco- 2 cells were grown for at least 21 days to allow formation physiologically and morphologically (polarization, differentiation) well developed confluent cell monolayers prior to initiating drug transport studies (Hidalgo et al. 1989; Vachon and Beaulieu 1992; Walle and Walle 1998).

\section{Monolayer integrity}

Two or three days before start of the experiment the monolayer integrity of each insert was checked by $500 \mu \mathrm{mol} / \mathrm{l}$ phenol red permeability (Fleet and Wood 1999; Garcia-Casal et al. 2000). After $1 \mathrm{~h}$ incubation of phenol red added to the apical side, $500 \mu \mathrm{l}$ sample from each insert was taken from basolateral side and measured by spectrophotometer Spekol 11 at $558 \mathrm{~nm}$.

The integrity of the monolayer during the transport studies was confirmed simultaneously by ${ }^{14} \mathrm{C}$-mannitol $(0.5 \mu \mathrm{Ci} / \mathrm{ml})$ permeability (Baird and Prosser 1998) done at least in triplicate. $50 \mu \mathrm{l}$ of apical or $500 \mu \mathrm{l}$ of basolateral samples were mixed with $10 \mathrm{ml}$ of the scintillation liquid and counted in the Beckman liquid scintillation analyser (LS 5000TD) for $1 \mathrm{~min}$.

\section{Transport studies}

Transport experiments were performed with HBSS transport medium (Walle and Walle 1998; Ingels and Augustijns 2003) buffered with $25 \mathrm{mmol} / \mathrm{l} \mathrm{HEPES} \mathrm{(pH} \mathrm{7.4)} \mathrm{or} 25 \mathrm{mmol} / \mathrm{l} \mathrm{MES}$ ( $\mathrm{pH}$ 6.0). The prepared Caco-2 cell inserts were rinsed twice with prewarm HBSS and equilibrated with $\mathrm{HBSS}$ at $37^{\circ} \mathrm{C}$ for $30 \mathrm{~min}$ before the transport experiments (Walle and Walle 1998).

The transport experiments from apical to basolateral (AP$\mathrm{BL}$ ) side were initiated by replacing the transport medium with the diluted ambroxol (100, 300 and $1000 \mu \mathrm{mol} / \mathrm{l})$ in the transport medium $(550 \mu \mathrm{l})$ on the apical side. The samples of $500 \mu \mathrm{l}$ from the basolateral compartment was withdrawn at 30, 60, 90 and $120 \mathrm{~min}$ for high performance liquid chromatography (HPLC) analysis and the same volume of the prewarmed transport medium was added to the basolateral compartment. Between sampling, the cells were kept in an incubator at $37^{\circ} \mathrm{C}$ and $5 \% \mathrm{CO}_{2}$.

Similarly, for basolateral to apical (BL-AP) transport, the drug was added to the basolateral compartment $(650 \mu \mathrm{l})$ and the volume of $300 \mu \mathrm{l}$ was withdrawn from the receiver side in the same time intervals.

All used solutions and transport media were sterile filtered just before the experiments. All experiments were carried out under sink conditions so that the concentrations of the drug in the receiver compartment would not exceed $10 \%$ of applicated dose in the donor side.

To determine paracellular component of the ambroxol transport $(300 \mu \mathrm{mol} / \mathrm{l})$ the $\mathrm{HBSS} \mathrm{Ca}^{2+}$-free was used (for washes, $30 \mathrm{~min}$ preincubation and for the transport study).

\section{Design of the experiments}

- AP-BL transport - absorptive direction (iso- $\mathrm{pH} 7.4=\mathrm{pH}$ 7.4 in both sides),

- BL-AP transport - secretory direction (iso-pH 7.4),

- AP-BL transport (pH 6 apical/pH 7.4 basolateral),

- AP-BL transport (pH 7.4 in both sides) with the $\mathrm{Ca}^{2+}$-free transport medium. 


\section{HPLC analysis of ambroxol}

The quantification of ambroxol was performed by HPLC. The modified method of Su et al. (2007) was used. Chromatographic separation was performed on an analytical column Discovery ${ }^{\circledR} \mathrm{C} 18(250 \times 4.6 \mathrm{~mm}, 5 \mu \mathrm{m}$; Supelco, USA $)$ with mobile phase consisting of $30 \mathrm{mmol} / \mathrm{l}$ ammonium acetate $(0.4 \%$ formic acid)-acetonitrile $(64: 36, \mathrm{v} / \mathrm{v})$ at a flow-rate of $1 \mathrm{ml} / \mathrm{min}$, the total run $7 \mathrm{~min}$ for each sample. Samples were diluted with mobile phase. Dextromethorphane was used as an internal standard. The detection and quantification was performed by UV detection at $242 \mathrm{~nm}$ (ambroxol) and $280 \mathrm{~nm}$ (dextromethorphane). The peak area was measured and the peak area ratio of ambroxol to internal standard was calculated. The linear calibration curve was assembled within the concentration range of $0.25-100 \mu \mathrm{mol} / \mathrm{l}(\mathrm{r}>0.999)$. Samples were stored at $-20^{\circ} \mathrm{C}$ until HPLC analysis.

\section{Data analysis}

\section{Cumulative transport of ambroxol}

Calculated cumulative amount of ambroxol (nmol) were plotted versus time.

\section{Percent transport of ambroxol}

Percent transport was calculated as the ratio of the cumulative concentration in the receiver chamber to the concentration in the donor chamber $\times 100$. Percent transport was plotted versus time.

\section{Calculation of the apparent permeability coefficient}

The apparent permeability coefficient $\left(\mathrm{P}_{\mathrm{app}}, \mathrm{cm} / \mathrm{s}\right)$ was calculated according to the equation (Artursson and Karlsson 1991):

$$
\mathrm{P}_{\text {app }}=(\mathrm{d} Q / \mathrm{d} t) \times\left(1 / \mathrm{A} \times \mathrm{C}_{0}\right)
$$

where $\mathrm{d} Q / \mathrm{d} t$ is the permeability rate, the amount of drug appearing in the receiver compartment in function of time $(\mathrm{nmol} / \mathrm{s}), \mathrm{C}_{0}$ is the initial concentration in the donor chamber $(\mathrm{nmol} / \mathrm{ml})$, and $\mathrm{A}$ is the surface area of the monolayer $\left(\mathrm{cm}^{2}\right)$.

\section{Calculation of the flux rate}

The flux rate $\left(\mathrm{nmol} / \mathrm{min} / \mathrm{cm}^{2}\right)$ of the ambroxol was determined from the slope of the plot of the cumulatively transported amount versus time using linear regression analysis and the flux rates were plotted versus ambroxol concentrations to investigate whether the flux rate is concentrationdependent/independent.

\section{Evaluation of the bidirectional flux}

Transport in both directions across monolayer enables to calculate an uptake or efflux ratio (Ungell and Karlsson 2004):

$$
\begin{aligned}
& \mathrm{P}_{\text {app }} \text { uptake ratio }=\mathrm{P}_{\text {app }} \mathrm{AP}-\mathrm{BL} / \mathrm{P}_{\text {app }} \mathrm{BL}-\mathrm{AP} \\
& \mathrm{P}_{\text {app }} \text { efflux ratio }=\mathrm{P}_{\text {app }} \mathrm{BL}-\mathrm{AP} / \mathrm{P}_{\text {app }} \mathrm{AP}-\mathrm{BL}
\end{aligned}
$$

\section{Calculation of recovery}

Recovery (mass balance) was calculated using the following equation:

recovery $(\%)=\left[\left(\mathrm{M}_{\mathrm{r}-120}+\mathrm{M}_{\mathrm{d}-120}\right) / \mathrm{M}_{\mathrm{d}-0}\right] \times 100$

where $\mathrm{M}_{\mathrm{r}-120}$ is the cumulative amount of drug transported to the receiver side at the end of the experiment, $\mathrm{M}_{\mathrm{d}-120}$ is the amount of drug remaining on the donor side at the end of the experiment, $\mathrm{M}_{\mathrm{d}-0}$ is the amount of drug on the donor side at the start of the experiment (Ungell and Karlsson 2004).

\section{Statistical analysis}

All values are represented as mean \pm SD (standard deviation). Statistical differences were determined using Kruskal-Wallis one way analysis of variance (ANOVA) with Mann-Whitney $\mathrm{U}$ test for double comparision or a Student's $t$-test. The differences were considered significant when $p<0.05$. All treatments were carried out at least in triplicate.

\section{Results}

\section{Ambroxol solubility}

Equilibrium solubility (Yazdanian et al. 2004) was 452 $\mu \mathrm{g} / \mathrm{ml}(1085 \mu \mathrm{mol} / \mathrm{l})$ in the transport medium HBSS ( $\mathrm{pH}$ 7.4). Our results of dose-relative solubility (Yazdanian et al. 2004) determined according to FDA (Food and Drug Administration) guidance on BCS ranged ambroxol among highly soluble drugs (Polli et al. 2004) as the highest dose strength $(60 \mathrm{mg})$ is soluble in $250 \mathrm{ml}$ over the $\mathrm{pH}$ range $1-7.5$.

\section{The assessment of the monolayer integrity}

The $\mathrm{P}_{\text {app }}$ value of phenol red after $1 \mathrm{~h}$ was $0.82 \pm 0.28 \times 10^{-6}$ $\mathrm{cm} / \mathrm{s}$ and percent cumulative transport reached $0.23 \pm 0.08 \%$. The phenol red recovery was $108 \pm 2.4 \%$.

The $\mathrm{P}_{\text {app }}$ of mannitol after $2 \mathrm{~h}$ was $2.26 \pm 0.62 \times 10^{-6}$ $\mathrm{cm} / \mathrm{s}$ and corresponded to the percent cumulative transport $1.63 \pm 0.44 \%$. The ${ }^{14} \mathrm{C}$-mannitol recovery was $107 \pm 2.2 \%$. There was no effect of ambroxol on the $\mathrm{P}_{\text {app }}$ of ${ }^{14} \mathrm{C}$-mannitol (Table 1). 
Table 1. Permeability, percent transport and efflux ratio of ambroxol across Caco-2 monolayer. Transport was observed in the AP-BL and $\mathrm{BL}-\mathrm{AP}$ directions under iso-pH 7.4 and $\mathrm{pH}$-gradient (6 vs. 7.4) conditions.

\begin{tabular}{|c|c|c|c|c|c|}
\hline \multirow[t]{2}{*}{$\begin{array}{l}\text { Compound } \\
\text { concentration }\end{array}$} & \multicolumn{2}{|c|}{$\begin{array}{c}\mathrm{P}_{\mathrm{app}} \\
\left(\mathrm{cm} / \mathrm{s} \times 10^{-6}\right)\end{array}$} & \multicolumn{2}{|c|}{$\begin{array}{c}\text { Percent transport } \\
(\%) \\
\end{array}$} & \multirow[t]{2}{*}{ Efflux ratio } \\
\hline & $\begin{array}{c}\text { AP-BL } \\
\mathrm{pH} 7.4-7.4\end{array}$ & $\begin{array}{c}\text { BL-AP } \\
\text { pH 7.4-7.4 }\end{array}$ & $\begin{array}{c}\text { AP-BL } \\
\text { pH 7.4-7.4 }\end{array}$ & $\begin{array}{c}\text { BL-AP } \\
\mathrm{pH} \text { 7.4-7.4 }\end{array}$ & \\
\hline Phenol red & $0.82 \pm 0.28$ & & $0.23 \pm 0.08$ & & \\
\hline Man & $2.26 \pm 0.62$ & & $1.63 \pm 0.44$ & & \\
\hline $\mathrm{Man}+\mathrm{Amb}(300 \mu \mathrm{mol} / \mathrm{l})$ & $2.10 \pm 0.25$ & & & & \\
\hline $\operatorname{Amb}(100 \mu \mathrm{mol} / \mathrm{l})$ & $37.75 \pm 1.15$ & $34.30 \pm 0.48$ & $27.18 \pm 0.67$ & $19.02 \pm 0.22$ & 0.90 \\
\hline $\operatorname{Amb}(300 \mu \mathrm{mol} / \mathrm{l})$ & $43.10 \pm 3.39^{* 1)}$ & $43.52 \pm 2.35^{\star 1)}$ & $30.92 \pm 2.65$ & $24.10 \pm 1.24^{\star 1)+}$ & 1.01 \\
\hline $\operatorname{Amb}(1000 \mu \mathrm{mol} / \mathrm{l})$ & $45.90 \pm 0.95$ & $43.27 \pm 5.17$ & $33.05 \pm 0.56$ & $23.97 \pm 2.34$ & 0.94 \\
\hline \multirow[b]{2}{*}{ Amb $(300 \mu \mathrm{mol} / \mathrm{l})$} & $\begin{array}{c}\text { AP-BL } \\
\text { pH 6-7.4 }\end{array}$ & & $\begin{array}{c}\text { AP-BL } \\
\text { pH 6-7.4 }\end{array}$ & & \\
\hline & $5.08 \pm 0.75^{\#}$ & & $3.66 \pm 0.38^{\#}$ & & \\
\hline
\end{tabular}

Effect of ambroxol concentration on $\mathrm{P}_{\mathrm{app}}$ values and percent transport. ${ }^{*}$ significant differences among ambroxol concentrations: ${ }^{\star 1)} 100$ vs. $300 \mu \mathrm{mol} / \mathrm{l},{ }^{\star 2)} 100 v s 1000 \mu \mathrm{mol} / \mathrm{l}$ (non significant), $\left.{ }^{\star 3}\right) 300 v s .1000 \mu \mathrm{mol} / \mathrm{l}$ (non significant). Ambroxol $\mathrm{P}_{\mathrm{app}}$ values and percent transport AP-BL vs. BL-AP: ${ }^{+}$significant differences between AP-BL and BL-AP directions. Effect of $\mathrm{pH}$ conditions on ambroxol $\mathrm{P}_{\mathrm{app}}$ values and percent transport: ${ }^{\#}$ significant difference in comparison with ambroxol (300 $\mu \mathrm{mol} / \mathrm{l}$ ) at iso-pH condition. Man, mannitol; Amb, ambroxol. Efflux ratio $=\mathrm{P}_{\mathrm{app}} \mathrm{BL}-\mathrm{AP} / \mathrm{P}_{\mathrm{app}} \mathrm{AP}-\mathrm{BL}$. Values are represented as mean $\pm \mathrm{SD}, p<0.05$.

\section{Transport studies}

\section{Cumulative transport of ambroxol}

The cumulative transport of ambroxol was linear for up to $2 \mathrm{~h}$ over the concentration range examined and was $\mathrm{pH}$ dependent (Fig. 1).

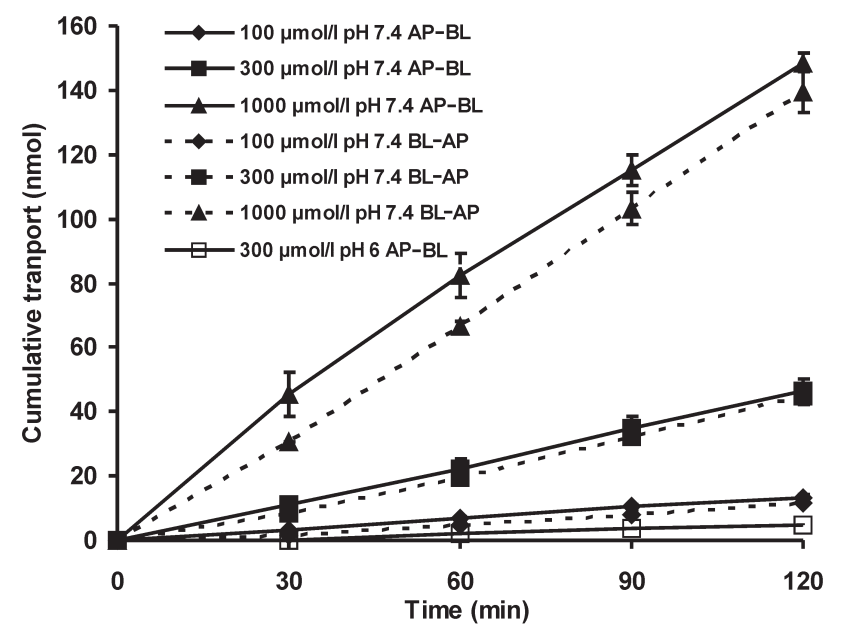

Figure 1. Time course of cumulative bidirectional transport: apical-basolateral (AP-BL; solid line) and basolateral-apical (BL-AP; dashed line) of ambroxol (100, 300 and $1000 \mu \mathrm{mol} / \mathrm{l})$ under iso-pH 7.4 and $\mathrm{pH}$-gradient ( 6 vs. 7.4) conditions. Each point represents the mean \pm SD of cumulative transport across Caco- 2 monolayers.

\section{Percent transport of ambroxol}

The transported cumulative amount of ambroxol (100, 300 and $1000 \mu \mathrm{mol} / \mathrm{l}$ ) expressed as a percentage of the amount added to the donor chamber ranged from 19 to $33 \%$ (Table 1 ). Percent transport in BL-AP direction was slightly lower then

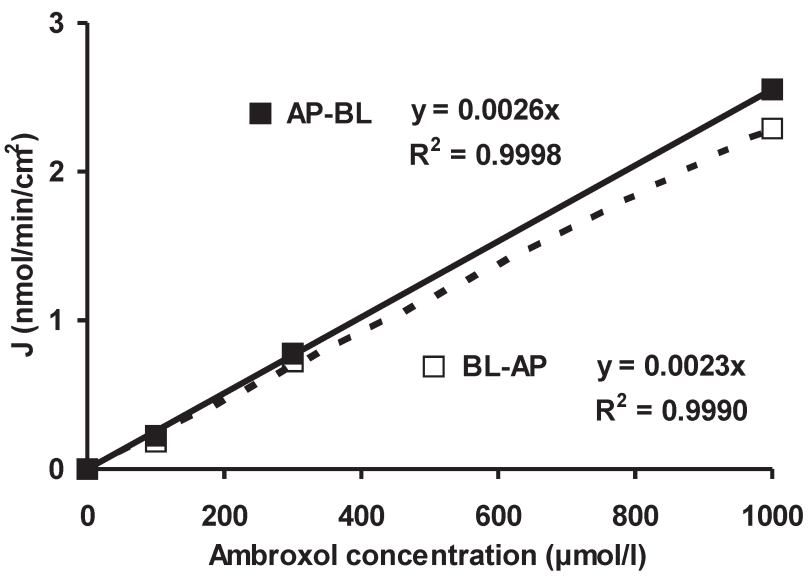

Figure 2. Comparison of AP-BL and BL-AP transport of ambroxol across Caco-2 monolayers. The flux rate J was determined in the time course (30-120 min) of AP-BL or BL-AP transport at various concentrations. The transport was characterized by linear regression analysis resulted in linear equation $\mathrm{y}=\mathrm{kx}$ and coefficient of determination $\mathrm{R}^{2}$. 


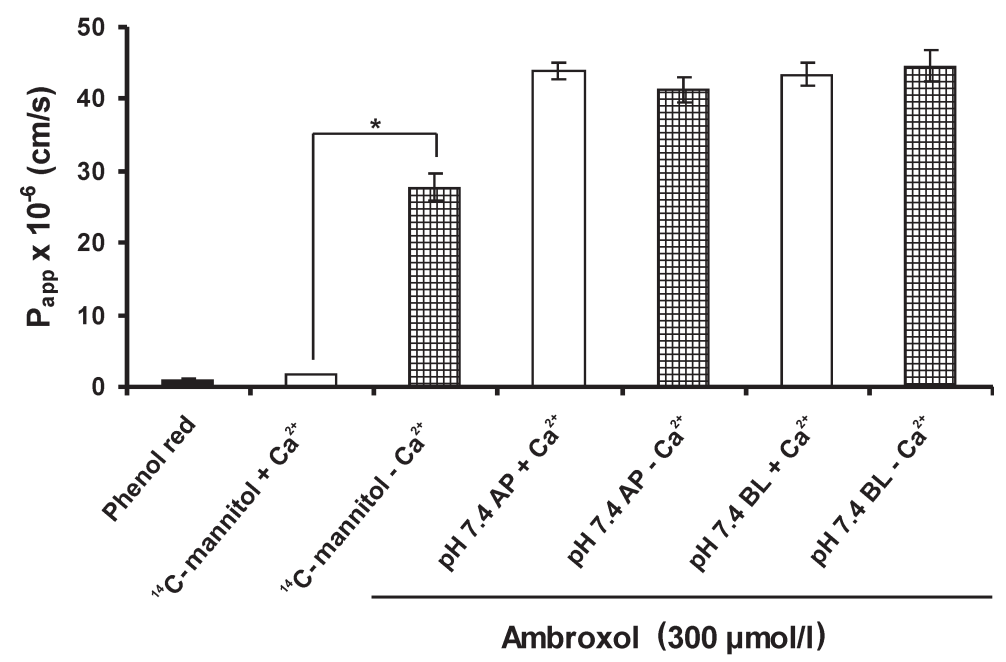

Figure 3. Ambroxol and ${ }^{14} \mathrm{C}$-mannitol (a marker of paracellular transport) permeability AP-BL in absence or presence of Ca ${ }^{2+}$ in transport medium. ${ }^{*}$ significantly different from values obtained in the presence of $\mathrm{Ca}^{2+}$. Each column represents the mean \pm SD of permeability coefficient $\left(\mathrm{P}_{\mathrm{app}}\right), p<0.05$.

AP-BL transport. Under the pH-gradient (pH 6 apical), the transported amount of ambroxol was significantly decreased and the percent transport reached only 3.7\% (Table 1).

\section{Calculation of $P_{a p p}$}

$\mathrm{P}_{\mathrm{app}}$ of ambroxol (Table 1) was independent of concentration over the entire concentration range $(100-1000 \mu \mathrm{mol} / \mathrm{l})$. The ambroxol $\mathrm{P}_{\text {app }}$ was $(43.1-45.9) \times 10^{-6} \mathrm{~cm} / \mathrm{s}$ at the concentration of 300 and $1000 \mu \mathrm{mol} / \mathrm{l}$ and slightly lower $\left(37.7 \times 10^{-6}\right.$ $\mathrm{cm} / \mathrm{s}$ ) at $100 \mu \mathrm{mol} / \mathrm{l}$. Furthermore, no differences in the $\mathrm{P}_{\mathrm{app}}$ of ambroxol in both directions at doses of 100, 300, 1000 $\mu \mathrm{mol} / \mathrm{l}$ were observed and the calculation of the efflux ratio oscillated around 1. At pH 6 in the donor apical chamber, the $\mathrm{P}_{\mathrm{app}}$ of ambroxol decreased approximately 8-times and was $5.1 \times 10^{-6} \mathrm{~cm} / \mathrm{s}$ (Table 1 ).

\section{Calculation of the flux rate}

The range of concentrations used (100-1000 $\mu \mathrm{mol} / \mathrm{l})$ was limited by the lack of ambroxol solubility in the transport medium $(1085 \mu \mathrm{mol} / \mathrm{l})$. AP-BL and BL-AP fluxes were simi$\operatorname{lar}\left(2.6\right.$ and $2.3 \mathrm{nmol} / \mathrm{min} / \mathrm{cm}^{2}$ at $\left.1000 \mu \mathrm{mol} / \mathrm{l}\right)$. The fluxes were a simple linear function of ambroxol concentrations, indicating passive diffusion (Fig. 2).

\section{Recovery}

The ambroxol recovery defined as the amount recovered in the apical and basolateral compartment at the end of the experiment oscillated about $90-95 \%$ for both directions.

\section{Evaluation of the paracellular transport}

The transport of the paracellularly transported ${ }^{14} \mathrm{C}$-mannitol was significantly enhanced 16-times by the use of HBSS $\mathrm{Ca}^{2+}$-free transport medium $\left(27.7 \times 10^{-6} \mathrm{~cm} / \mathrm{s}\right)$ in comparison with transport medium with $\mathrm{Ca}^{2+}$. However, the $\mathrm{P}_{\text {app }}$ of ambroxol in both transport directions was not changed (Fig. 3) and oscillated about $43 \times 10^{-6} \mathrm{~cm} / \mathrm{s}$.

\section{Discussion}

BCS devised by Amidon et al. (1995) categorizes drugs into four classes according to their solubility and permeability which are the fundamental parameters controlling rate and extent of drug absorption.

To predict the oral absorption of drugs in humans, the drug permeability determined in Caco- 2 cell monolayers (one of the in vitro models for studying membrane permeability and oral absorption) is used (Van de Waterbeemd 2005). Despite the well documented activity and pharmacokinetics of ambroxol after oral administration, there are few published data available on the exact transport mechanisms. Thus, the purpose of this study was to characterize the transepithelial transport mechanisms of ambroxol across the Caco-2 cell monolayer system as a model of human intestinal absorption in vitro.

The transport parameters of ambroxol were monitored for $2 \mathrm{~h}$ (corresponding to time to reach ambroxol peak plasma concentration in humans) (Vergin et al. 1985) in the AP-BL (absorptive), as well as in the BL-AP (secretive) direction. No superiority in any transport direction was seen. The cumula- 
tive amount transported with respect to time showed that the transport was linear with time in both directions, and was concentration- and $\mathrm{pH}$-dependent. Furthermore, similar cumulative percent transport plotted versus time for all tested ambroxol concentrations (100, 300 and $1000 \mu \mathrm{mol} / \mathrm{l})$ and for both directions signalized the passive, non-saturable process. Small differences observed (slightly lower percent transport from basolateral compartment than from apical compartment) may be a consequence of differences in the surface areas of the apical and basolateral side of the monolayer and volume differences of the donor compartments.

Our findings of similar $\mathrm{P}_{\text {app }}$ values and the efflux ratio (0.9-1) over the ambroxol concentration range (100-1000 $\mu \mathrm{mol} / \mathrm{l})$ and no observed difference between the flux rates in the two opposite directions also suggested a passive diffusion mechanism of the ambroxol transport across the Caco-2 monolayers.

As hydrochloride form of ambroxol was used, the possibility of paracellular transport was supposed. However, the molecular weight of ambroxol hydrochloride 414.6 is a limiting factor for this transport pathway. The molecular weight limit for the Caco-2 monolayer seems to be $300 \mathrm{~g} / \mathrm{mol}$ (Ungell and Karlsson 2004). Also the high value of ambroxol $\mathrm{P}_{\text {app }}\left(45 \times 10^{-6} \mathrm{~cm} / \mathrm{s}\right)$ indicated transcellular transport. In general, compounds limited to paracellular transport are not efficiently absorbed across the Caco-2 monolayer due to the small available absorptive area and the restriction caused by tight junctions (Ungell and Karlsson 2004).

The assessment of the paracellular component of the transport in the Caco-2 cells can be studied with opening the tight junctions by using the $\mathrm{Ca}^{2+}$-free transport medium (Delie and Rubas 1997; Ungell and Karlsson 2004; McMillan et al. 2005). When this $\mathrm{Ca}^{2+}$-free medium was used, the $\mathrm{P}_{\mathrm{app}}$ of ${ }^{14} \mathrm{C}$-mannitol (positive control for the paracellular pathway) was significantly increased but the $\mathrm{P}_{\text {app }}$ of ambroxol was not enhanced. According to this fact it can be concluded that there is no evidence for the paracellular mechanism of ambroxol transport.

We also studied the effect of $\mathrm{pH}$ that is a very important factor affecting absorption of ionizable drugs in the gastrointestinal tract. $\mathrm{pH}$ demonstrates two main effects on drugs: 1. the effect on the degree of dissociation of weak electrolytes and thereby affection of the passive compound diffusion, and 2. the effect on the establishment of a proton gradient as a driving force for some transporters. The $\mathrm{pH}$ of the apical solution has a direct impact on the transport experiments using monolayers, since the solution is in direct contact with the membrane and should therefore mimic the microclimate $\mathrm{pH}$. Our experimental schedule applying $\mathrm{pH}$ gradient $(6.0$ vs. 7.4) better reflect the gradient under physiological condition and also reflect the absorption across the jejunum (the main part of absorption of most drugs) (Ungell and Karlsson 2004). The passive diffusion of ambroxol as a weak base was enormously decreased at $\mathrm{pH}$ 6. Obtained results are in a good agreement with the theoretical assumption of transport mechanisms in gastrointestinal tract for weak bases in acid conditions: lowering of the $\mathrm{pH}$ increases ionization of weak bases and decreases their permeability.

Taken together obtained results showed that the transport of ambroxol seems to be transcellular mediated by passive diffusion.

Determined high permeability of ambroxol and dose-relative high solubility enable to classify ambroxol as class I of BCS.

Regarding prediction of ambroxol fraction absorbed, transport rates of passively absorbed drugs in the Caco2 cells have been shown to correlate with the fraction absorbed in humans (Artursson and Karlsson 1991; Lennernäs et al. 1996). The high $\mathrm{P}_{\mathrm{app}}$ of ambroxol $\left(45 \times 10^{-6}\right.$ $\mathrm{cm} / \mathrm{s}$ ) ranged ambroxol among well-absorbed compounds (Yee 1997). From the nomogram (Ungell and Karlsson 2004) showing the oral fraction of different drugs absorbed in humans plotted versus their $\mathrm{P}_{\mathrm{app}}$ obtained in Caco-2 cell monolayers it can be approximated that the fraction of ambroxol absorbed in humans is high, reaching almost $100 \%$. Predicted ambroxol absorbed fraction corresponds with the high absolute bioavailability $70-83 \%$ reached in human studies (lower bioavailability of ambroxol determined in human studies - in spite of its rapid and extensive absorption after oral administration - is probably caused by hepatic first-pass effect (Hammer et al. 1978; Vergin et al. 1985).

\section{Conclusion}

The results of our experiments in the Caco- 2 monolayer model showed that the ambroxol transport is linear with time, pH-dependent and direction-independent, displays non-saturable (first-order) kinetics. Thus, the transport of ambroxol seems to follow the transcellular passive diffusion. The high solubility and high permeability classifying ambroxol as class I of BCS indicates a well-absorbed compound. It can be supposed that the oral dose fraction of ambroxol absorbed in humans is high.

Acknowledgements. The experimental part of the study was supported by research project GAČR 305/08/0535. The authors wish to thank Ms. Hana Machová for her skilful technical assistance.

\section{References}

Amidon G. J., Lennernäs H., Shah V. P., Crison J. R. (1995): A theoretical basis for a biopharmaceutic drug classification: the correlation of in vitro drug product dissolution and in vivo bioavailability. Pharm. Res. 12, 413-420; doi:10.1023/A:1016212804288 
Artursson P., Karlsson J. (1991): Correlation between oral drug absorption in humans and apparent drug permeability coefficients in human intestinal epithelial (Caco-2) cells. Biochem. Biophys. Res. Commun. 175, 880-885; doi:10.1016/0006-291X(91)91647-U

Artursson P., Palm K., Luthman K. (2001): Caco-2 monolayers in experimental and theoretical predictions of drug transport. Adv. Drug Deliv. Rev. 46, 27-43; doi:10.1016/S0169409X(00)00128-9

Artursson P., Bergström C. A. S. (2004): Intestinal absorption: the role of polar surface area. In: Drug Bioavailability. (Eds. H. Waterbeemd, H. Lennernäs and P. Artursson), pp. 341-357, (2nd edition), Wiley-Vch. Verlag GmbH\&Co. KGaA, Weinheim

Baird A. W., Prosser E. S. (1998): Cell culture models for polarized epithelial monolayers. In: Animal Cell Culture Techniques. (Ed. M. Clynes), pp. 298-318, Springer-Verlag, Berlin- Heidelberg-New York

Bourdet D. L., Thakker D. R. (2006): Saturable absorptive transport of the hydrophilic organic cation ranitidine in Caco-2 cells: role of $\mathrm{pH}$-dependent organic cation uptake system and P-glycoprotein. Pharm. Res. 23, 1165-1177; doi:10.1007/s11095-006-0251-4

Delie F., Rubas W. (1997): A human colonic cell line sharing similarities with enterocytes as a model to examine oral absorption: advantages and limitations of the Caco-2 model. Crit. Rev. Ther. Drug Carrier Syst. 14, 221-286

Disse B. G. (1987): The pharmacology of ambroxol - review and new results. Eur. J. Respir. Dis. 71, 255-262

Fleet J. C., Wood R. J. (1999): Specific 1,25(OH)2D3-mediated regulation of transcellular calcium transport in Caco- 2 cells. Am. J. Physiol., Gastrointest. Liver Physiol. 276, G958-964

Garcia-Casal M. N., Leets I., Layrisse M. (2000): $\beta$-carotene and inhibitors of iron absorption modify iron uptake by Caco2 cells. J. Nutr. 130, 5-9

Hammer R., Bozler G., Jauch R., Koss F. W. (1978): Ambroxol, comparative studies of pharmacokinetics and biotransformation in rat, rabbit, dog and man. Arzneim.-Forsch. 28, 899-903 (in German)

Hidalgo I. J., Raub T. J., Borchardt R. T. (1989): Characterization of the human colon carcinoma cell line (Caco-2) as a model system for intestinal epithelial permeability. Gastroenterology 96, 736-749

Ingels F. M., Augustijns P. F. (2003): Biological, pharmaceutical, and analytical considerations with respect to the transport media used in the absorption screening system, Caco-2. J. Pharm. Sci. 92, 1545-1558; doi:10.1002/jps.10408

Lennernäs H., Palm K., Fagerholm U., Artursson P. (1996): Comparison between active and passive drug transport in human intestinal epithelial (Caco-2) cells in vitro and human jejunum in vivo. Int. J. Pharm. 127, 103-107; doi:10.1016/0378-5173(95)04204-0

Malerba M., Ragnoli B. (2008): Ambroxol in the 21st century: pharmacological and clinical update. Expert Opin. Drug Metab. Toxicol. 4, 1119-1129; doi:10.1517/ 17425255.4.8.1119

McMillan J. M., Walle U. K., Walle T. (2005): S-adenosyl-L-methionine: transcellular transport and uptake by Caco- 2 cells and hepatocytes. J. Pharm. Pharmacol. 57, 599-605; doi:10.1211/0022357056082

Polli J. E., Yu L. X., Cook J. A., Amidon G. L., Borchardt R. T., Burnside B. A., Burton P. S., Chen M. L., Conner D. P., Faustino P. J., Hawi A. A., Hussain A. S., Joshi H. N., Kwei G., Lee V. H. L., Lesko L. J., Lipper R. A., Loper A. E., Nerurkar S. G., Polli J. W., Sanvordeker D. R., Taneja R., Uppoor R. S., Vattikonda C. S., Wilding I., Zhang G. (2004): Summary workshop report: biopharmaceutics classification system - implementation challenges and extension opportunities. J. Pharm. Sci. 93, 1375-1381; doi:10.1002/jps.20064

Püschmann S., Engelhorn R. (1978): Pharmacological study on the bromhexine metabolite ambroxol. Arzneim.-Forsch. 28, 889-898 (in German)

Su F., Wang. F., Gao W., Li H. (2007): Determination of ambroxol in human plasma by high performance liquid chromatography-electrospray ionization mass spektrometry (HPLC-MS/ESI). J. Chromatogr., B: Biomed. Appl. 853, 364-368; doi:10.1016/j.jchromb.2007.03.015

Štětinová V., Herout V., Květina J. (2004): In vitro and in vivo antioxidant activity of ambroxol. Clin. Exp. Med. 4, 152-158; doi:10.1007/s10238-004-0050-3

Ungell A.-L., Karlsson J. (2004): Cell culture in drug discovery: an industrial perspective. In: Drug Bioavailability. (Eds. H. Waterbeemd, H. Lennernäs and P. Artursson), pp. 90-131, (2nd edition), Wiley-Vch. Verlag GmbH\&Co. KGaA, Weinheim

Vachon P. H., Beaulieu J.-F. (1992): Transient mosaic patterns of morphological and functional differentiation in the Caco2 cell line. Gastroenterology 103, 414-423

Vergin H., Bishop-Freundling G. B., Miczka M., Nitsche V., Strobel K., Matzkies F. (1985): The pharmacokinetics and bioequivalence of various dosage forms of ambroxol. Arzneim.-Forsch. 35, 1591-1595 (in German)

Van de Waterbeemd H. (2005): Which in vitro screens guide the prediction of oral absorption and volume of distribution? Basic Clin. Pharmacol. Toxicol. 96, 162-166; doi:10.1111/ j.1742-7843.2005.pto960304.x

Wu C.-Y., Benet L. Z. (2005): Predicting drug disposition via application of BCS: transport/absorption/elimination interplay and development of a biopharmaceutics drug disposition classification system. Pharm. Res. 22, 11-23; doi:10.1007/s11095-004-9004-4

Walle U. K., Walle T. (1998): Taxol transport by human intestinal epithelial Caco-2 cells. Drug Metab. Dispos. 26, 343-346

Yazdanian M., Briggs K., Jankovsky C., Hawi A. (2004): The "high solubility" definition of the current FDA Guidance on Biopharmaceutical Classification System may be too strict for acidic drugs. Pharm. Res. 21, 293-299; doi:10.1023/B: PHAM.0000016242.48642.71

Yee S. (1997): In vitro permeability across Caco-2 cells (colonic) can predict in vivo (small intestinal) absorption in manfact or myth. Pharm. Res. 14, 763-766; doi:10.1023/ A:1012102522787

Received: January 30, 2009

Final version accepted: April 6, 2009 